\title{
Fabrication of c-Si solar cells using boric acid as a spin-on dopant for back surface field
}

\begin{abstract}
Gajendra Singh, ${ }^{a}$ Amit Verma ${ }^{b}$ and R. Jeyakumar*a
Cost effective solar cells are paramount for solar power to compete with traditional power generation. Here we present results on two low cost, both side textured c-Si solar cells. One solar cell had an Al back surface field (BSF), while the other had boron BSF fabricated by using spin-on boric acid as a p-type dopant. As compared to the Al-BSF solar cell, an improvement in efficiency of $1.7 \%$ was observed for a solar cell with boron BSF. Since boron BSF is stronger than Al-BSF, an improvement in efficiency can be attributed to an increase in long wavelength response, collection efficiency and reduced back surface recombination. The boron BSF solar cell showed an efficiency of $12.9 \%$ with $V_{\text {oc }}$ of $0.56 \mathrm{~V}, J_{\text {sc }}$ of 32.2 $\mathrm{mA} \mathrm{cm} \mathrm{cm}^{-2}$ and FF of 0.72 . These parameters are expected to significantly increase further with the addition of layers such as anti-reflection/passivation layers at the front side, and back surface passivation with local back surface field, etc.
\end{abstract}

Received 11th October 2013 Accepted 5th November 2013

DOI: 10.1039/c3ra45746j

www.rsc.org/advances be avoided by using B-BSF. ${ }^{1}$ Therefore, B-BSF is superior to Al-BSF. ${ }^{1,3}$

Here we report comparative results on experimental characterization of two low cost c-Si based solar cells that combine the advantages of different technologies. In one type, the BSF region was formed by e-beam evaporation of $\mathrm{Al}$ followed by rapid thermal processing (RTP). In another type, the BSF region was formed by spin-coating boron, followed by RTP. Fig. 1 illustrates the cross-sectional view of the fabricated solar cells. Conceptually the solar cells work as follows. Incident light generates electron-hole pairs in the p-type c-Si absorber layer. The electrons travel to the top towards the $\mathrm{p}-\mathrm{n}$ junction, and are in turn collected by the metal grid pattern. Holes, on the other hand, travel across bulk $\mathrm{Si}$ and are collected by the $\mathrm{Al}$ electrode. The potential barrier at the $\mathrm{p}-\mathrm{p}^{+}$junction (Fig. 2) provides an additional mechanism to drive electrons away from reaching the back contact and towards the $\mathrm{p}-\mathrm{n}$ junction through a field created by a $\mathrm{p}-\mathrm{p}^{+}$junction in the base, thereby increasing the short-circuit current density $\left(J_{\mathrm{sc}}\right)$ and open-circuit voltage $\left(V_{\mathrm{oc}}\right)$ due to reduced recombination at the rear surface. Fig. 2 shows the energy band diagram of $\mathrm{p}^{+}-\mathrm{p}-\mathrm{n}^{+}$solar cell corresponding to the schematic diagram shown in Fig. 1. boron at the rear surface is higher $\left(2 \times 10^{20} \mathrm{~cm}^{-3}\right)^{3}$ than that of $\mathrm{Al}$. This results in a low BSRV due to heavy $\mathrm{p}^{+}$doping at the rear surface and isolates the $\mathrm{p}^{+}-\mathrm{p}$ junction from the high recombination region that exists under the screen printed rear side contact. ${ }^{1}$ Also, stress induced bow in thin Si wafer can

${ }^{a}$ Physics of Energy Harvesting Division, National Physical Laboratory, Dr. K. S. Krishnan Road, Pusa Campus, New Delhi 110 012, India. E-mail: ramanuj@ nplindia.org

${ }^{b}$ Department of Electrical Engineering, Texas A\&M University-Kingsville, 700 University Blvd, Kingsville, TX 78363, USA

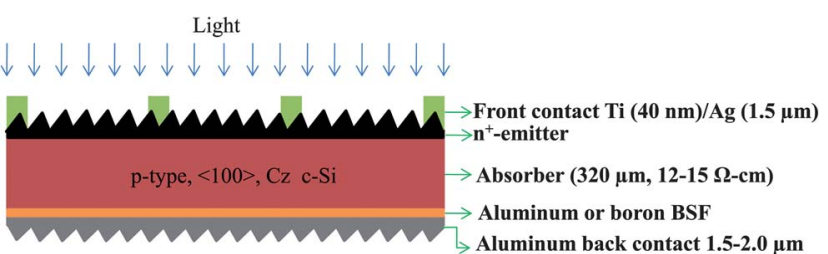

Fig. 1 Schematic cross-section of c-Si solar cell. High performance features have not been used. 


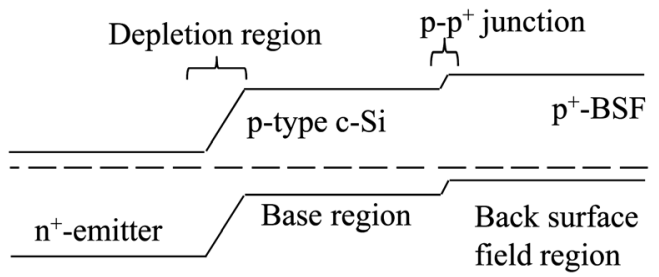

Fig. 2 Energy band diagram of $\mathrm{p}^{+}-\mathrm{p}-\mathrm{n}^{+}$type $\mathrm{c}-\mathrm{Si}$ solar cell. The potential barrier ( $p-p^{+}$junction) between the lightly doped and heavily doped region keeps the minority carriers (in this case, electrons) in the lightly doped region and away from back contact.

In Section 2 we outline the experimental details of fabrication process and characterization steps for the two types of cells. Results and discussions are drawn in Section 3.

\section{Experimental details}

Fig. 3 and 4 shows the process sequences for boron-BSF and AlBSF solar cells. We have used as-cut, p-type, $320 \mu \mathrm{m}$ thick, $\langle 100\rangle$ oriented, $2^{\prime \prime} \mathrm{Cz}$ c-Si wafers with resistivity 12-15 $\Omega \mathrm{cm}$. Below we provide the details of the fabrication process.

\subsection{Saw damage removal}

The fabrication started with saw damage removal of c-Si wafers. Saw damages were removed using hot alkaline solution containing $20 \% \mathrm{NaOH}$ dissolved in DI water. Si wafers were kept in the solution at $80{ }^{\circ} \mathrm{C}$ for $20 \mathrm{~min}$. The following etching reaction takes place: ${ }^{4}$

$$
\mathrm{Si}+2 \mathrm{H}_{2} \mathrm{O}+\mathrm{HO}^{-} \rightarrow \mathrm{HSiO}_{3}^{-}+2 \mathrm{H}_{2}
$$

The above etching reaction takes place in three steps, viz. (i) oxidation of $\mathrm{Si}$, (ii) soluble salt formation, and (iii) dissolution
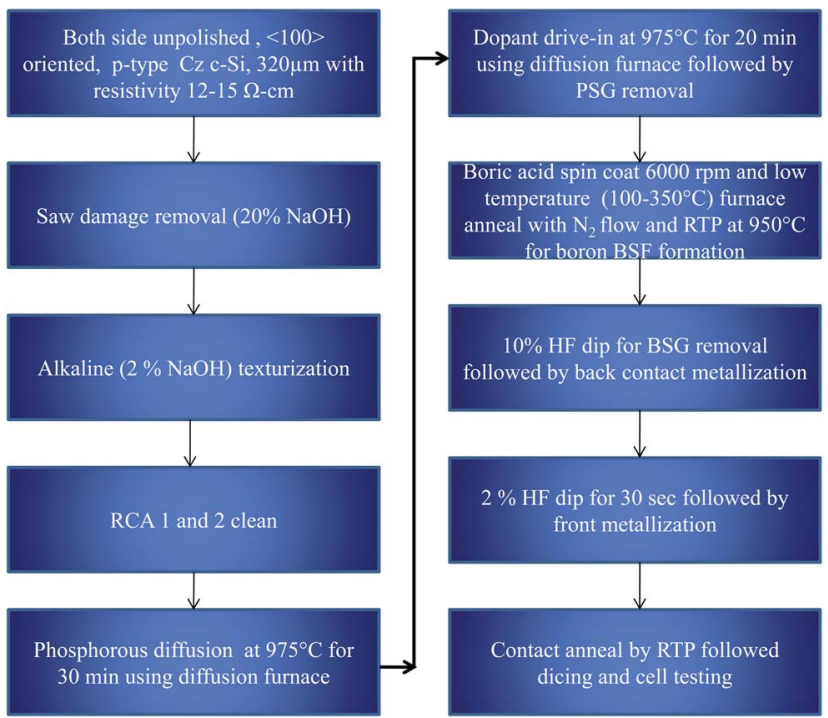

Fig. 3 Flow chart showing the process sequence for boron-BSF solar cell.

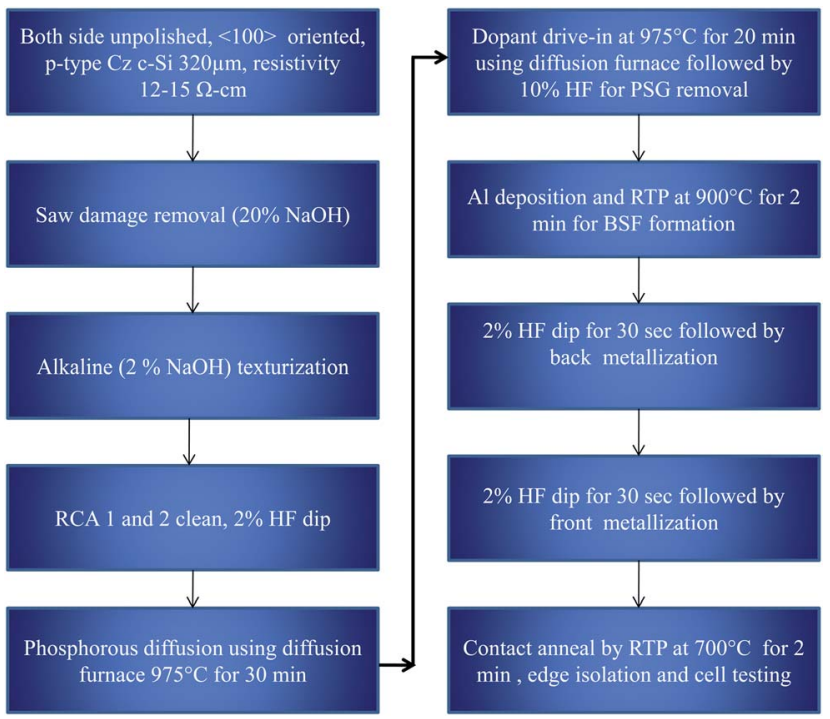

Fig. 4 Flow chart showing the fabrication process for Al-BSF solar cell.

of salt in the DI water. Saw damage removal enhances mechanical strength of the wafer and reduces surface recombination. About $30 \mu \mathrm{m}$ of the damaged surface (i.e. $15 \mu \mathrm{m}$ on each side) was removed during the etching process since saw damage penetrates about $10 \mu \mathrm{m}$ deep into the wafer surface. ${ }^{4}$

\subsection{Texturization}

After cleaning with DI water and nitrogen dry, the wafers underwent texturization by anisotropic etching of the front and back surfaces of the c-Si absorber. A texturized surface has the effect of causing multiple reflections of incident photons, and consequently increasing probability of light absorption. Due to texturization, total reflection of light from a c-Si wafer has been reported to reduce from about $35 \%$ to $11 \%,{ }^{5}$ with an improvement in optical absorption closer to the $\mathrm{p}-\mathrm{n}$ junction. Therefore $J_{\text {sc }}$ is also improved. In our work, sodium hydroxide $(\mathrm{NaOH})$ was used as an alkaline etchant for texturization on both sides of the c-Si wafer. Isopropyl alcohol (IPA) was added to the alkaline etchant to improve the uniformity of the random pyramid

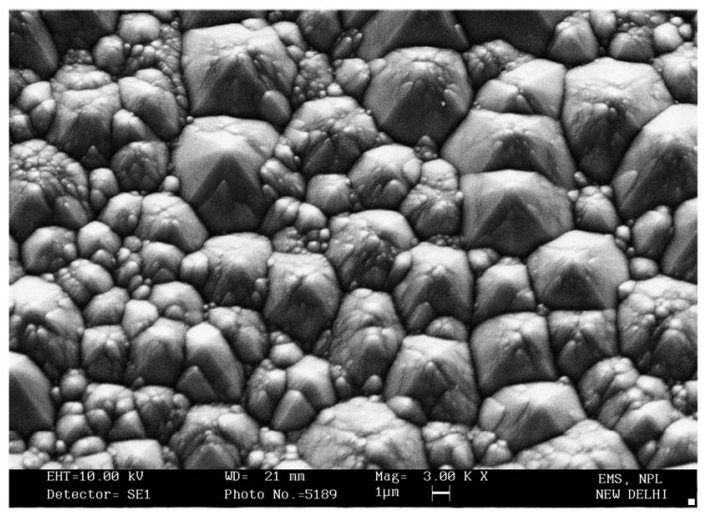

Fig. 5 SEM image shows textured c-Si surface. 


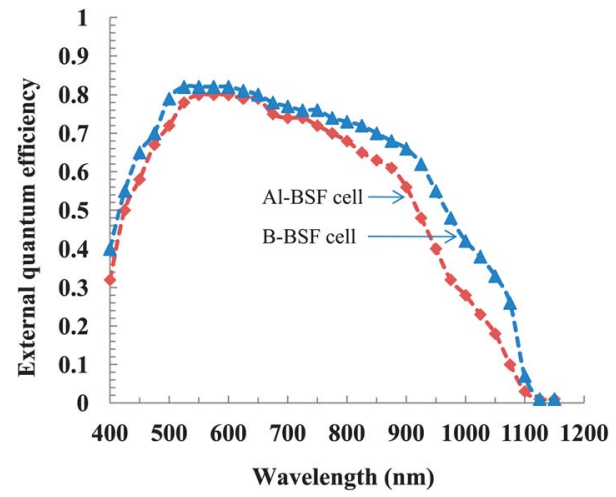

Fig. 6 External quantum efficiency of boron-BSF and Al-BSF solar cells.

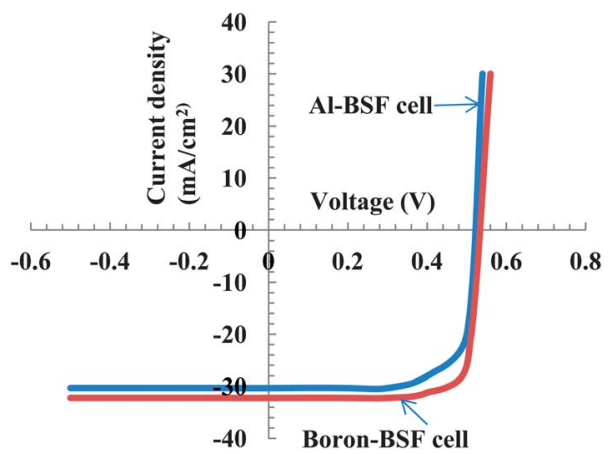

Fig. 7 Light I-V characteristics for Al-BSF solar cell and boron-BSF solar cell.

Table 1 Output parameters for Al-BSF cell and boron-BSF cell

\begin{tabular}{lllll}
\hline Sample & $\begin{array}{l}V_{\mathrm{oc}} \\
(\mathrm{mV})\end{array}$ & $\begin{array}{l}J_{\mathrm{sc}} \\
\left(\mathrm{mA} \mathrm{cm}^{-2}\right)\end{array}$ & $\begin{array}{l}\mathrm{FF} \\
(\%)\end{array}$ & $\begin{array}{l}\text { Efficiency } \\
(\%)\end{array}$ \\
\hline Al-BSF cell & 540 & 30.3 & 68 & 11.2 \\
Boron-BSF cell & 560 & 32.2 & 72 & 12.9 \\
\hline
\end{tabular}

texture. An anisotropic chemical wet etch forms pyramids in the order of $\mu \mathrm{m}$ on the c-Si surface. The composition of the solution is as follows:

$$
390 \mathrm{ml} \mathrm{DI}+10 \mathrm{~g} \mathrm{NaOH}+80 \mathrm{ml} \text { IPA }
$$

The above solution was heated between $80{ }^{\circ} \mathrm{C}$ and $85^{\circ} \mathrm{C}$ and the wafers were immersed in the solution for various times between 30 and $45 \mathrm{~min}$. IPA is essential, even though it is relatively expensive, since it removes hydrogen bubbles sticking on the Si wafer by improving the wettability of the c-Si surface. On the other hand, etching rate of c-Si decreases with IPA concentration. ${ }^{6}$ IPA is volatile in the heated solution and so, to maintain the wettability of the Si surface, IPA was added to the solution during the texturization process to compensate for the amount lost due to evaporation. After texturization, the wafers underwent standard RCA cleaning for emitter diffusion. The scanning electron microscopy (model: LEO 440 PC Based Digital System SEM) system was used to aid in optimization of texturization.

\subsection{Emitter (phosphorous) diffusion}

Phosphorous diffusion was performed for emitter formation. In this process, phosphorous diffuses into $\mathrm{Si}$ and forms $\mathrm{p}-\mathrm{n}$ junctions with a p-type base. The solid phosphorous source was a $2^{\prime \prime}$ ceramic wafer that contains phosphorous pentoxide $\left(\mathrm{P}_{2} \mathrm{O}_{5}\right)$. During 30 min pre-deposition process at $975{ }^{\circ} \mathrm{C}, \mathrm{P}_{2} \mathrm{O}_{5}$ evaporates from the ceramic wafer and condenses as a thin layer onto the Si wafer. This thin layer provides elemental phosphorous for diffusion into $\mathrm{Si}$ and the following reaction takes place:

$$
2 \mathrm{P}_{2} \mathrm{O}_{5}+5 \mathrm{Si} \rightarrow 4 \mathrm{P}+5 \mathrm{SiO}_{2}
$$

In the above equation (b), $\mathrm{P}+\mathrm{SiO}_{2}$ known as phosphorous silicate glass (PSG). The pre-deposition process is known as PSG layer deposition in which a shallow diffusion of phosphorous atoms occurs. The PSG layer becomes the source of phosphorous for diffusion. After the pre-deposition step, the dopant source (ceramic wafer) was removed and phosphorous atoms diffused deeper (i.e. redistributed) to a desired depth into Si by a drive-in diffusion step performed at $975{ }^{\circ} \mathrm{C}$ for $20 \mathrm{~min}$. Drive-in diffusion determines junction depth. After drive-in diffusion, the PSG layer was etched away using $10 \%$ hydrofluoric acid solution. In this two-step (pre-deposition and drive-in) process, phosphorous diffuses into $\mathrm{Si}$ and forms a $\mathrm{p}-\mathrm{n}$ junction with the p-type base. Diffusion temperature and time are adjusted such that the surface carrier concentration reaches $\sim 10^{19} \mathrm{~cm}^{-3}$. Excess amounts of phosphorous atoms $\left(>2 \times 10^{20} \mathrm{~cm}^{-3}\right)^{7}$ in the Si surface region forms a dead layer (i.e. inactive phosphorous), which increases carrier recombination since it is difficult to passivate excessive doped surface. This results in a decrease in $V_{\mathrm{oc}}, J_{\mathrm{sc}}$ and cell efficiency. After emitter diffusion, sheet resistance measurements were performed by a four probe technique.

\subsection{Back surface field formation}

For one wafer, hereafter called cell 1 , the wafer was cleaned with DI water and nitrogen dry. A $6 \mathrm{wt} \%$ of boric acid was dissolved in DI water $(18 \mathrm{M} \Omega \mathrm{cm})$. After this, $3-5 \mathrm{~mL}$ of boric acid was spin coated at 6000 RPM for 1 min on the back of the cell for BSF formation. Boric acid $\left(\mathrm{H}_{3} \mathrm{BO}_{3}\right)$ as spin-on dopant has been reported in ref. 1,3 and 8.

Boric acid $\left(\mathrm{H}_{3} \mathrm{BO}_{3}\right)$ is a hydrate of boric oxide $\left(\mathrm{B}_{2} \mathrm{O}_{3}\right)$ and exists in crystalline phase. ${ }^{9}$ Diffusion of boron into $\mathrm{Si}$ from boric acid involves formation of meta boric acid and then dehydration of boric acid. From boric acid, metaboric acid $\left(\mathrm{HBO}_{2}\right)$ is formed first at approximately $130{ }^{\circ} \mathrm{C}$ (ref. 9) and then anhydrous boric oxide $\left(\mathrm{B}_{2} \mathrm{O}_{3}\right)$ forms when heated $>250^{\circ} \mathrm{C}$. At a temperature of $350{ }^{\circ} \mathrm{C}$, more than $90 \mathrm{wt} \% \mathrm{HBO}_{2}$ contains $\mathrm{B}_{2} \mathrm{O}_{3} \cdot{ }^{10}$

For solar cell applications, boron diffusions are performed above $900{ }^{\circ} \mathrm{C}$ (ref. 3 and 8) irrespective of the boron sources. ${ }^{1}$ Heavily doped $\mathrm{p}^{+}$layers can be formed using boric acid solution and can be passivated equivalent to those formed using boron 
tribromide and solid sources. ${ }^{1,3}$ In our work, the boric acid film was cured at $130^{\circ} \mathrm{C}$ to remove moisture from the film and then cured at $250{ }^{\circ} \mathrm{C}$ and $350{ }^{\circ} \mathrm{C}$ (ref. 8) in a furnace under inert $\mathrm{N}_{2}$ atmosphere. As the curing temperature increases, $\mathrm{H}_{3} \mathrm{BO}_{3}$ dehydrates and forms metaboric acid $\left(\mathrm{HBO}_{2}\right)$ and boron oxide $\left(\mathrm{B}_{2} \mathrm{O}_{3}\right)$ as mentioned in eqn (c)-(e) (ref. 11) below.

$$
\begin{gathered}
\mathrm{H}_{3} \mathrm{BO}_{3} \rightarrow \mathrm{HBO}_{2}+\mathrm{H}_{2} \mathrm{O} \\
2 \mathrm{HBO}_{2} \rightarrow \mathrm{B}_{2} \mathrm{O}_{3}+\mathrm{H}_{2} \mathrm{O} \\
3 \mathrm{H}_{3} \mathrm{BO}_{3} \rightarrow \mathrm{B}_{2} \mathrm{O}_{3}+3 \mathrm{H}_{2} \mathrm{O}
\end{gathered}
$$

At $900{ }^{\circ} \mathrm{C}$, diffusion of boron atoms into $\mathrm{Si}$ occurs ${ }^{10,12}$ through equation (f). $\mathrm{B}_{2} \mathrm{O}_{3}$ reacts with $\mathrm{Si}$ and forms $\mathrm{SiO}_{2}$ and boron.

$$
2 \mathrm{~B}_{2} \mathrm{O}_{3}(\mathrm{l})+3 \mathrm{Si}(\mathrm{s}) \rightarrow 4 \mathrm{~B}(\mathrm{~s})+3 \mathrm{SiO}_{2}(\mathrm{~s})
$$

RTP was performed at $950{ }^{\circ} \mathrm{C}$ (AnnealSys, AS-One 150) for 2 min. At a high temperature around $900{ }^{\circ} \mathrm{C}$, boron diffuses into $\mathrm{Si}^{\mathbf{1 3}}$ and dissolves in liquid $\mathrm{Si}$ and distributes uniformly along the depth of the Si wafer. A borosilicate glass (BSG) layer formed during BSF formation was removed by $10 \%$ HF solution.

For another cell, hereafter referred to as cell 2, a 2\% HF dip and DI water clean was performed right before $\mathrm{Al}$ deposition, and to form BSF, $2 \mu \mathrm{m}$ thick $\mathrm{Al}$ was e-beam evaporated on the back surface followed by 2 min RTP annealing at $900{ }^{\circ} \mathrm{C}$ in $\mathrm{N}_{2}$ atmosphere. Therefore cell 1 was a boron-BSF cell, while cell 2 was an Al-BSF cell.

\subsection{Contact metallization and cell isolation}

For cell 1 and 2, a short 2\% HF dip was given to remove native oxides on the rear surface. This was followed by rear contact blanket $\mathrm{Al}$ metallization $(1.5 \mu \mathrm{m})$ by e-beam evaporation (Hind High Vacuum, model 15F6). After another HF dip, a Ti (40 $\mathrm{nm}) / \mathrm{Ag}(1.5 \mu \mathrm{m})$ top finger grid pattern was formed through a shadow mask. Contact annealing was done by RTP at $700{ }^{\circ} \mathrm{C}$ for $2 \mathrm{~min}$ in $\mathrm{N}_{2}$ atmosphere. Edge isolation was performed by laser cutting around the grid pattern formed at the centre of the wafer. The final cell 1 and cell 2 total areas were $2 \times 2 \mathrm{~cm}^{2}$ each.

\section{Results and discussion}

Random pyramid texturization for both surfaces was optimized at $85{ }^{\circ} \mathrm{C}$ for $30 \mathrm{~min}$ using $2 \% \mathrm{NaOH}$ and $8-10 \%$ isopropyl alcohol in DI water. Different conditions led to either nonuniform texturization (such as in our case when the c-Si wafers were kept in the $2 \% \mathrm{NaOH}+8-10 \%$ IPA solution at $80{ }^{\circ} \mathrm{C}$ for 30 min, texturization did not cover the entire wafer surface), or formation of sharp tops. The latter accounts for insufficient coverage and contact by each layer leading to poor cell performance. ${ }^{14}$ Smoothing of sharp tops improves conformal film deposition and enhances $V_{\text {oc }}$ and minority carrier lifetime. ${ }^{15}$ Texturization in $2 \% \mathrm{NaOH}+8-10 \%$ IPA at $85{ }^{\circ} \mathrm{C}$ for 30 minutes were found to be the optimum conditions for uniform texturization. Fig. 5 shows a high resolution SEM picture of the optimized texturized c-Si wafer used for the fabrication of solar cells.

Emitter sheet resistance and rear side sheet resistance for the Al-BSF cell and boron-BSF cell were determined by a four point probe method. For the Al-BSF cell, emitter sheet resistance and rear side Al-Si alloy sheet resistance were found to be $52 \Omega$ per square and $65 \Omega$ per square, respectively. For the boron-BSF cell, emitter sheet resistance was the same as the previous case since the processing conditions were the same. For a spin-on boric acid concentration between 1 and $6 \mathrm{wt} \%$, a boron-Si alloy sheet resistance between 47 and $44 \Omega$ per square was obtained and was almost independent of boric acid concentration. Lee et al. ${ }^{3}$ has reported that boron solubility in $\mathrm{Si}$ is higher than that of $\mathrm{Al}$ and hence boron concentration in the $\mathrm{B}-\mathrm{Si}$ alloy is higher than $\mathrm{Al}$ concentration in the Al-Si alloy. Therefore, rear side surface recombination is reduced for boron-BSF due to the heavy doping.

Solar cell performance parameters were measured at $25{ }^{\circ} \mathrm{C}$ by AM 1.5 solar simulator (Bunkoukeiki Co. Ltd, model no. CEP-25HS-50). Fig. 6 shows the external quantum efficiency (EQE) of boron-BSF and Al-BSF cells. As compared to the AlBSF cell, high EQE has been obtained for the boron-BSF cell. An improved spectral response and hence EQE particularly in the long wavelength region might be due to low surface recombination velocity at the rear side. Our results are in agreement with those reported earlier, ${ }^{1}$ in which back surface recombination velocity and back surface reflectance has been reported, respectively, as $210 \mathrm{~cm} \mathrm{~s}^{-1}\left(600 \mathrm{~cm} \mathrm{~s}^{-1}\right)$ and $93 \%$ $(60 \%)$ for the boron-BSF cell (Al-BSF cell). According to Lee et al., ${ }^{3}$ for the Al-BSF cell, high back surface recombination velocity at the $\mathrm{Al}-\mathrm{Si}$ contact is due to low $\mathrm{Al}$ concentration in the Ai-Si alloy, which is $<3 \times 10^{18} \mathrm{~cm}^{-3}$. The $I-V$ characteristics of the solar cells are shown in Fig. 7. Table 1 lists the output parameters for both cells. As can be seen, compared to the Al-BSF cell, an improvement in efficiency of $1.7 \%$ was obtained for the boron-BSF cell.

\section{Conclusions}

We have presented experimental characterization comparative results on two low-cost Si solar cells. Both cells were approximately identical, with the significant difference being the BSF region. In one cell, the $\mathrm{BSF}$ was formed through $\mathrm{Al}$, deposited by e-beam evaporation followed by RTP, while in the second cell, the BSF was formed by spin coating boric acid and then performing RTP. Both solar cells are cost-effective since the photolithography process and high performance features such as anti-reflection coating/passivation layer, rear side passivation, local BSF etc. have not been used. The boron-BSF cell shows a higher efficiency of $12.9 \%$, compared to the $11.2 \%$ shown by the Al-BSF solar cell. For both solar cells, the measured efficiencies represent the lower bound efficiency. As is normally the case with traditional Si solar cells, these efficiencies are expected to significantly increase further with the addition of efficiency improving (i.e. high performance) features. 


\section{References}

1 A. Das, D. S. Kim, K. Nakayashiki, B. Rounsaville, V. Meemongkolkiat and A. Rohatgi, Boron diffusion with boric acid for high efficiency silicon solar cells, J. Electrochem. Soc., 2010, 157, H684-H687.

2 P. Lolgen, W. C. Sinke, C. Leguijt, A. W. Weeberet, P. F. A. Alkemade and L. A. Verhoef, Boron doping of silicon using coalloying with aluminium, Appl. Phys. Lett., 1994, 65, 2792-2794.

3 J. Y. Lee and S. H. Lee, Boron back surface field using spin-on dopants by rapid thermal processing, J. Korean Phys. Soc., 2004, 44, 1581-1586.

4 D.-H. Neuhaus and A. Munzer, Industrial silicon wafer solar cells, Adv. OptoElectron., 2007, 1-15, DOI: 10.1155/2007/24521.

5 R. Chaouia, B. Mahmoudia and Y. S. Ahmeda, Improvement of screen-printed textured monocrystalline silicon solar cell performance by metal-assisted chemical etching, Energy Proc., 2013, 36, 253-259.

6 I. Zubel and M. Kramkowska, The effect of isopropyl alcohol on etching rate and roughness of (100) Si surface etched in $\mathrm{KOH}$ and TMAH solutions, Sens. Actuators, A, 2001, 93, 138-147.

7 F. C. Marques, J. Urdanivia and I. Chambouleyron, A simple technology to improve crystalline-silicon solar cell efficiency, Sol. Energy Mater. Sol. Cells, 1998, 52, 285-292.

8 D. S. Kim, A. Das, K. Nakayashiki, B. Rounsaville, V. Meemongkolkiat and A. Rohatgi, Proc. 22nd Eur.
Photovoltaic Solar Energy Conf. Exhib., Milan, Italy, 3-7, September 2007, pp. 1730-1733.

9 G. V. Samsonov, L. Y. Markovskii, A. F. Zhigach and M. G. Valyashko, Boron, its compounds and alloys, Academy of Sciences of the Ukrainian SSR, Kiev, 1960, U. S. Atomic Energy Commission, Translation Series.

10 C. Zhou, Y. Tang, W. Wang, S. Zhou, L. Zhao, H. Li and H. Diao, Preparation of $\mathrm{p}$--layers using water vapour as oxidant in $\mathrm{BBr}_{3}$ diffusion for silicon solar cells, J. Phys. D: Appl. Phys., 2013, 46, 285102.

11 F. C. Kracek, G. W. Morey and H. E. Merwin, The system, Water-Boron oxide, Am. J. Sci., 1938, 35A, 143-171.

12 M. W. Chase, C. A. Davis, J. R. Downey, D. J. Frurip, R. A. McDonald and A. N. Syverud, JANAF Thermochemical Tables, J. Phys. Chem. Ref. Data, 1985, 14(1), 1163.

13 E. Arai, H. Nakamura and Y. Terunuma, Interface reactions of $\mathrm{B}_{2} \mathrm{O}_{3}-\mathrm{Si}$ system and boron diffusion into silicon, J. Electrochem. Soc., 1973, 120, 980-987.

14 J. Zhenyu, D. Yuhua, Z. Yu, Z. Yuqin, L. Fengzhen and Z. Meifang, Effect of chemical polish etching and post annealing on the performance of silicon heterojunction solar cells, J. Semicond., 2009, 30, 084010.

15 I. Kashkoush, G. Chen, D. Nemeth and J. Rieker, Optimized wet processes and PECVD for high-efficiency solar cells, http:/www.akrionsystems.com/wp-content/uploads/2012/01/ optimized-wet-processes-and-pecvd-for-high-efficiency-solarcells.pdf. 